\title{
European Union issues
}

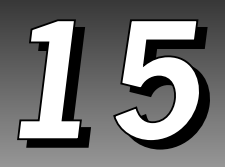

Descriptions of the main issues facing the European Union

Review of these issues

Speculations as to the future course of the issues

\section{THE DEMOCRATIC DEFICIT AND INSTITUTIONAL REFORM}

\section{The nature of the democratic deficit}

The issues concerning individual institutions of the European Union are described in chapter 14, on EU Institutions. However, a number of general remarks can be made at this stage. The main concerns which politicians from member countries and commentators have include the following:

- It is generally felt that the institutions of the European Union are not accountable enough.

- There is too much secrecy in the EU and too much of its proceedings are carried out behind closed doors. This is connected with the lack of accountability, as it is clear that if the public and their elected representatives are not provided with information, they will be unable to make judgements about the performance of the institutions.

- Representation in much of the EU is indirect. The Parliament is elected, but no other bodies are (unless we accept that the Council of Ministers is indirectly elected).

- No decision-making bodies have a clear mandate. The public of Europe cannot, therefore, judge how well their political leaders are responding to their demands.

- There is no European constitution. The political system of the EU has been formed though the various treaties which have been negotiated since 1957. This means that the relationships between the institutions are not clear. 
There is a lack of a system of 'checks and balances' within the system. For example, the Parliament is a single chamber, without an upper house to check its power, Parliament itself has limited powers over the executive branch (i.e. the Commission and Council of Ministers combined). The European Court of Justice does provide some degree of control, but the absence of a constitution means they have little documentary evidence on which to base their decisions.

Some member countries such as the UK and Denmark have argued that there cannot be any further political integration until the democratic deficit is addressed. Others, such as Germany and Italy, on the other hand, have suggested that, if Europe can move towards a federal system, many of these problems will be automatically resolved. Meanwhile the impending enlargement of the Union makes the need for democratic reforms more pressing. The new members will want their interests safeguarded and will be unwilling to accept the general lack of accountability. The democratic problem is particularly acute for those countries, such as Poland and the Czech Republic, who have quite recently escaped from the yoke of totalitarian communist regimes.

\section{Some solutions}

In recognition of these problems the European Union set up a Constitutional Convention in the spring of 2002 under the chairmanship of Valery Giscard d'Estaing, a former French President. With over a hundred delegates from both existing and prospective members, it has been given eighteen months to report back on political and constitutional reform. If the Convention fails, the future progress of the EU will be seriously impeded. Should it produce workable and effective proposals, the prospects for greater integration will be enhanced.

What kind of issues and possible solutions will the d'Estaing Convention consider?

- Reform of the Parliament to make it more representative, accountable and effective.

- Changing the nature of the Commission, probably making it more accountable, possibly making arrangements for more control over appointments by the Parliament. It may also recommend popular elections to the Commission. The way in which the Commission works may also be made more transparent.

- The relationships between the Commission, Council of Ministers and Parliament will be reviewed to make decision making clearer and more efficient.

- The problem of the lack of political leadership for the EU may be addressed. It is conceivable that there will be a proposal for an elected President for the Union. 
- A British idea is that there should be a bicameral legislature. Some kind of second parliamentary chamber is certainly on the cards.

- There are proposals for a European 'Bill of Rights' which would, once and for all, establish the basis of citizenship and rights for all members of the EU, including its millions of new citizens to come.

- Students, academics, media people and politicians may now enjoy a year or two of speculation, but after d'Estaing reports, it will be up to the heads of government to make key decisions in this area.

\section{THE COMMON AGRICULTURAL POLICY}

The Common Agricultural Policy (CAP) was created in 1960, a time when there were only six members of the Community. Its founders can, therefore, be forgiven for not foreseeing the many problems which would arise when new members were admitted. It has to be said that it was France which was the prime mover in the CAP and it was seen as a price which had to paid for France's continued membership. It had a number of objectives:

1 To guarantee the incomes of farmers (and wine growers) even in markets which are extremely volatile.

2 To prevent agricultural prices from rising too much when there is an unexpected supply shortage. In this way consumers can be protected.

3 To ensure that European agriculture can survive in the face of world competition, system of price supports and subsidies provided protection.

4 Ultimately it was hoped that the Community could become self-sufficient in food. To some extent this was the result of memories of the post-World War II period, when there were severe food shortages. This aim had been achieved by 1973 .

The ways in which these objectives have been pursued constitute a wide range of systems of intervention. The main measures are:

Subsidies to try to ensure that some agricultural sectors can survive despite low market prices and to maintain high output levels.

A price support and levy system to protect some sectors from external competition. If prices fall below a certain level which will not give farmers sufficient income, tariffs are placed on imports to hold up the price.

- Quota systems in those sectors where there is long-term over-production with the danger that prices will fall too low to sustain farm incomes. Each country, region and individual farm may be given a maximum quota or production limit. In this way the total production of the EU is controlled. Milk, for example, is produced under this system. 
Stock intervention is also used in some sectors. This is a scheme which prevents prices rising too much by releasing stockpiled goods onto the market and so keeping the price down. More often, however, it is a system of buying up stocks in order to hold up the price. This is the most controversial aspect of the CAP as it works against the interests of consumers by keeping prices artificially high. It has also resulted in huge wasteful stocks of goods building up and sometimes having to be destroyed. There have, in the past, been infamous 'wine lakes' and beef or butter 'mountains'.

Over-production is a major problem in the CAP. In the 1990s, therefore, a system known as 'set-aside' was developed. This was a device where farmers were actually paid to take land out of production altogether.

\section{Problems and reform}

An attempt to reform the system in 1965 failed when France exercised its veto. The consequent deadlock was broken in 1966 by the so-called 'Luxembourg Compromise'. This plan meant that the Council of Ministers would retain control over the CAP and that each member would be able to retain a veto over key decisions. The EU was saved, but has been saddled ever since with the problem that reform of the CAP has been made difficult by the power of each country to block change.

Ever since then, the CAP has proved to be one of the most unpopular aspects of the EU and certainly the most difficult to reform. Indeed, the CAP illustrates one of the most important problems for the EU as a whole. National interests show themselves to be at their most powerful when agriculture is at stake. Member governments are reluctant to alienate their own agricultural interests and so fight tenaciously to protect them when agriculture meetings are held. The idea of a 'supranational' body controlling agriculture seems out of the question for many years to come.

The most frustrating aspect of the CAP for those who do not have an interest in agriculture, is this difficulty in instituting reform. Indeed, for most members of the European public, complete abolition of the CAP seems the best option. The CAP is unpopular for a number of reasons.

- It eats up a huge portion of the EU budget. It is the taxpayers who pick up this bill. In 2000 a total of 41.5 billion euros was spent on the CAP, nearly a half of the total EU budget.

- It is seen to be supporting farmers, irrespective of whether they deserve this support.

- It is a system of trade protection. This raises food prices in Europe and discriminates against Third World producers. Campaigners argue that the system keeps Third World farmers poor, while European farmers grow rich. 
- The huge quantities of unused intervention stocks are viewed as obscene when large parts of the world are on or over the verge of starvation.

- Those countries which do not have large agricultural sectors, the UK being a prime example, resent the fact that it favours countries which do rely more on their own agricultural industries.

With the many problems which the CAP throws up, it is hardly surprising that frequent attempts at reform have been made. Two main stages of reform can be identified. The first was in 1992 when the set-aside system was introduced and began to slow-down over-production and so reduced the need for interventions in the market. Over-production of cereals and oils was partly tackled in this way. The second tranche of reforms came in 1999 when some subsidies, for example on cereals and beef, began to be progressively reduced (not least because the World Trade Organisation has been working towards a progressive reduction in protective tariffs and subsidies). To some extent countries were also allowed to apply to divert former subsidies into environmental projects. Britain is the most enthusiastic supporter of this new innovation and has a target of converting $20 \%$ of agricultural subsidies into environment schemes. This new system effectively pays farmers to reduce their output and become guardians of the environment instead.

Under the pressures of enlargement after 2004, the CAP will have to reform itself more radically. The main issues in this area are discussed in the next section. It may well be that the enlargement issue will become the fillip needed to break the influence of powerful farming interests in Western Europe.

\section{ENLARGEMENT}

The increases in the size of the EU up to the end of the twentieth century created relatively few problems (see table 15.1). The countries which joined late were already economically well developed and, by and large, had fully democratic political systems. There were, therefore, relatively few problems over their ability to make contributions and the demands which might have been placed on the Union budget. Fears that the membership of Greece and Portugal - the two poorest of the first fifteen members - might be disruptive, were largely unfounded. The post-2004 entries, however, were to be of a very different character. 
Table 15.1 Stages of EU enlargement, 1957-95

\begin{tabular}{ll}
\hline Year & Entrants \\
\hline 1957 & France, Germany, Italy, Belgium, Netherlands, Luxembourg \\
1973 & UK, Ireland, Denmark \\
1981 & Greece \\
1986 & Spain, Portugal \\
1995 & Sweden, Finland, Austria \\
\hline
\end{tabular}

\section{Conditions of entry}

States which wish to enter the EU must conform to a number of conditions according to the Treaty of Rome. These are:

1 They must accept all existing EU legislation.

2 They must be members of NATO (to avoid any conflict of interest over foreign and defence policy).

3 They must have adequate safeguards for human rights.

4 They must have democratic political systems.

5 Their economies should be basically capitalist. This does not prevent some public ownership of industry and public services, but, essentially, free markets must be allowed to operate. Otherwise, Europe would no longer be a truly single market.

6 They must be experiencing reasonable healthy rates of economic growth. This does not mean that they have to be particularly wealthy, but that at least they are moving forward economically.

7 Since the original conditions were set, it has also been added that new entrants have to adopt the euro as their currency (after a suitable transition period).

These conditions are mainly there to protect the interests of the existing members. However, they have also proved to be an incentive for the candidate countries. Many of the prospective entrants are former communist regimes who are desperately trying to restructure themselves economically and politically after the end of the Cold War and the collapse of the Soviet Union in 1990-91. The criteria for entry have encouraged them to introduce free markets, introduce democratic institutions and improve human rights. It will be for the Commission to make a judgement on these criteria, although the final decision on new members will be made in the European Council.

\section{The way forward}

The prospective members of the EU have been negotiating for some time, but the general plan for the admission of new states was agreed at Nice in 2000 . The following scheme is in place: 
- First wave (2003-4?). Cyprus, Czech Republic, Poland, Slovenia, Hungary, Estonia.

- Second wave (2007?). Bulgaria, Slovakia, Latvia, Lithuania, Romania, Malta.

- Third wave (?). Turkey, Croatia, Bosnia.

- Distant future. Russia, Ukraine, Belarus.

Although the agreement of the Nice Treaty of 2000 to enlarge the EU on the lines shown above was held up when the Irish voted against it in a referendum (ratification of the Nice Treaty requires unanimous approval), it is confidently expected that these countries will enter close to the scheduled date.

\section{The benefits of enlargement}

Although there remain a number of fears about enlargement (shown below), there has been a considerable amount of enthusiasm for admitting new entrants. Indeed, it was Margaret Thatcher who pushed the agenda forward in the 1980s. Her motivation was a belief that a larger community would also be diluted. She feared closer political integration and believed that, the more members there were, the more difficult it would be to achieve it. In the 1980s in general, there was a broad debate between the idea of 'widening' and 'deepening'. In the end, the larger members such as France and Germany, came to the conclusion that both could be managed at the same time, much to the chagrin of a sceptical Conservative Party. Apart from Thatcher's hopes, there are a considerable number of other perceived benefits:

- Enlargement into eastern and central Europe will finally confirm the end of the Cold War divide. In other words Europe will feel more permanently secure as a result of integration.

- It will speed up the process of democratisation and improving human rights throughout Europe.

The size of the market will grow considerably. This will widen the opportunities for European companies.

- As the European single economy grows, there will be new opportunities for greater specialisation and the benefits which that brings. Economists understand that the larger market, the more specialisation with free exchange, the growing size of industrial or commercial enterprises and increased competition will all promote growth and efficiency.

- The increased size of the euro-zone will create a bigger and more stable world currency - indeed it will become the dominant world currency, replacing the dollar in that position. 
In terms of geopolitics, Europe will become a major world power (provided it succeeds in being able to develop a common position of foreign policy). This may bring benefits in terms of trade and stability.

\section{Potential problems}

The effects of enlargement are not all one-sided. It is recognised that many problems will emerge. Most European politicians believe that the balance of evidence favours admitting new countries, but this does not mean that the perils can be ignored. Some of the expected difficulties are as follows:

There will be a huge strain on the Common Agricultural Policy. Many of the new entrants have strong agricultural sectors. Were they do enter on the same terms as existing members, it would mean huge amounts would have to be spent on price support systems and subsidies. There would also be a danger of even greater over-production - one of the CAP's main bugbears. The prospect of the EU having to buy up huge stocks of unsold cereals, dairy products, wine and meat simply to maintain high farm incomes, is not an attractive one. It follows that the whole of the CAP will have to be re-negotiated. Western European farmers will have to accept that the levels of support they currently enjoy cannot continue. Whatever the size of the agricultural 'cake' in the future, farmers are going to have to share it out more liberally.

Staying with agriculture, two more problems may well emerge from the creation of a much bigger single market. The first is the danger that farm units will become much bigger as levels of competition increase. The development of huge industrial farms, especially in Europe's so called central 'breadbasket' in Poland and Hungary would have serious adverse environmental effects (memories of the great American 'dustbowl', which was created in the 1930s, spring to mind). Secondly, an even more powerful agricultural bloc would damage further the interests of the Third World. If an enlarged European agricultural system were to continue with protective policies, there might be even less opportunities for poor farmers from the 'south' to penetrate the market.

The prospective members are considerably poorer than the current ones. This will place a strain on the regional development programme of the EU. It is recognised that subsidies for the poorer parts of Europe will have long-term benefits for all - larger markets, greater competition etc. - but in the short and medium terms, this will be a huge burden on the Community budget. It may be difficult to persuade taxpayers that some sacrifices now, which hit them hard, will lead to benefits later which will be much less tangible.

There are many, on both the political right and left, who fear the influx of huge numbers of economic refugees into Western Europe. In other words, admitting new members may open the floodgates to new immigrants. There are two 
aspects to this. Firstly - largely a right wing concern - it has a cultural element. With potentially huge movements of ethnic populations around Europe it is feared that there will be a major threat posed against traditional Western European cultures. Secondly - where trade unions are worried - there are economic concerns. Labour in the candidate countries is cheap. Some of this labour is likely to move into western Europe, attracted by higher wages and better conditions. This is likely to have the effect of depressing levels of pay. It is good news for consumers who may see prices fall, but bad news for existing workers who will see their wages and job security threatened.

Apart from these main potential problems, there is a collection of concerns which are more contentious. Some, for example, fear the import of organised crime from eastern Europe. Similarly there is a suspicion that the way will be more open for the infiltration of illegal drugs. Business groups have also expressed fears that they will find it difficult to deal with their counterparts in the new members as their normal practices are so different from those in western Europe.

\section{Enlargement and the political institutions}

One final set of problems can be treated separately. These concern the changes will be needed to the Union's political structure. The effects of enlargement will be far-reaching, but here we can introduce the three most pressing issues.

\section{Parliament}

With many new MEPs the Parliament would become simply too big. It therefore seems likely that existing representatives will have to cope with much larger constituencies. A British suggestion is that a second chamber will be needed in order to represent the regions of Europe as existing MEPs will find it difficult to do so. We have already alluded to the fragmentation of the Parliament in the chapter on institutions (14). With perhaps 25 or 30 members in the future, the range of national groupings increases again. Lessons may have to be learned from the experience of the USA, where the Senate return two members from each state, no matter its size, while the House of Representatives returns members from large constituencies and is expected to reflect their regional concerns.

\section{The commission}

As things stood in 2002 each member state was entitled to one of the twenty commissioner posts. The largest five were allowed two. The purpose of this device was to ensure that each state at least felt represented at senior level. With further enlargement, it will not be possible for every member to send a 
commissioner to Brussels. It is accepted, therefore, that some countries in the future ill not be able to have a commissioner. This is likely to prove a contentious issue in the future.

\section{The Council of Ministers}

Enlargement does not present a problem in terms of numbers. However, a much larger Council does create difficulties with decision making. On those issues where a unanimous decision is required it will become increasingly difficult to reach a conclusion. In order to get round this problem, it is expected that even more decisions will have to become subject to qualified majority voting. This is all very well and will make decision-making more effective. However, the larger states are likely to become concerned that they may be outvoted by a large coalition of smaller states. The new voting strengths in the Council, which were negotiated at Nice in 2000, go some way to prevent this, but it remains a future concern. It is in the fields of defence and foreign policy that this issue is likely to be most acute.

\section{A common defence and foreign policy for Europe}

When the Maastricht Treaty was negotiated in 1992, a general intention to forge a common system of foreign and defence policy was made. The impetus for this initiative came from the conflict which had broken out in the Balkans in the 1990s following the collapse of Yugoslavia.

The Balkans was the first major armed conflict to break out in Europe after World War II. It had the effect of alerting political leaders to the fact that Europe was going to have to take greater responsibility for its own internal security. External defence would continue to be provided by NATO, but NATO had proved to be an unwieldy organisation to deal with a complex issue like the Balkans war. Attempts to adopt a common European position in Bosnia had largely failed, so that a more permanent apparatus had to be found. There was an organisation in place to deal with such issues - the Organisation for Security and Co-operation in Europe (OSCE) - but it proved to be a toothless body, lacking the authority of the European Union or NATO. Progress has been slow, but this is likely to be an issue for many years to come. The conflicts on Kosovo and Macedonia which followed Bosnia have served as reminders to EU leaders that a long-term solution needs to be found.

\section{Foreign policy}

The Common Foreign and Security Policy (CFSP) was confirmed by the Amsterdam Treaty in 1997. Two years later a new post of CFSP High Representative was created and its first holder, Javier Solana, was appointed. This 
was an important first step, as it is vital for the EU to be able to negotiate with other states and organisations through a single individual, otherwise any messages are likely to become confused and lack authority. Solana has a planning unit to assist him, but the development of an extensive, permanent, supranational body in charge of foreign policy is slower in coming.

Foreign policy remains in the hands of intergovernmental bodies - the Council of Foreign Ministers and the European Council (of heads of government). This makes foreign policy making difficult. Key decisions require unanimous approval in these councils and every issue becomes an ad hoc negotiation, in other words each is treated separately. The requirement to reach agreement among foreign ministers and heads of governments presents a number of serious problems.

Member states have existing alliances of their own which may cut across European Union interests. Britain, for example, has a close relationship with the USA and Israel and has loyalties to Commonwealth countries. Italy and France have close links with Arab countries in the middle east, while Germany has a special interest in Turkey and the Balkans.

- Some countries, such as Sweden, Ireland and Austria now have traditions of neutrality which may be compromised by a common European foreign policy.

- The simple fact that fifteen countries (more after enlargement) have to reach agreement on very sensitive subjects is a huge stumbling block to decisive policy making.

- When foreign policy requires military backing - or at least the threat of it there may be no guarantee that member states will support their intentions with such a commitment.

Some states are, quite simply, less committed to European integration than others. This phenomenon is likely to vary as governments change, which they inevitably do. The British and Danish governments have, for example, been traditionally 'stand-offish'.

Although the European project is designed to end conflict, we have to accept that old rivalries die hard, making the reconciliation of foreign policy difficult. France - normally a fiercely nationalistic state - finds it hard to come to agreement with Germany and the UK, the Dutch are naturally suspicious of Germany, while Scandinavian countries have traditionally little interest in southern Europe.

Thus, until most of the members are willing to sacrifice this highly sensitive aspect of national sovereignty to supranational bodies, it is likely to remain a problematic subject. 


\section{Defence}

The difficulties involved in a common defence policy for the EU are perhaps more acute than those involved in foreign policy. Yet, surprisingly, progress has been more impressive. At a series of meetings in St Malo, Cologne, Washington and Helsinki in 1998-99 the idea of how Europe could move towards an independent, integrated defence capability was thrashed out. The agreement of the USA was sought and obtained, with various conditions, mainly safeguarding the role of NATO.

It was Britain's Tony Blair who solved the inevitable misgivings which some members had. He proposed a small, highly flexible force of about 60,000 soldiers. This was far from being a 'European Army' which opponents, mainly Conservatives, had suspected. It was described instead as a 'rapid reaction force'. For larger operations it was agreed that the European force should be effectively the armed forces of the Western European Union (WEU) which is a section of NATO without the USA. By insisting that the WEU would be the major European force, the relationship with NATO was preserved and protected. The WEU cannot act without the wider agreement of NATO as a whole. In this way the USA retained an interest in European defence issues.

At Helsinki in 2000 a permanent defence establishment was created and represents a considerable amount of progress. The bodies which came into existence are:

- the Political and Security Committee;

- the European Military Committee;

- the European Military Staff.

Despite the apparently successful outcome of the negotiations, there remain a number of problems with control of a European force.

- The command structure of the force is a major problem, despite the existence of the European Military Staff. It may be difficult for armed forces to accept the command of officers who are not of the same nationality. This may not be a problem in peacetime, but could be a major concern on the battlefield.

- Armed forces need political direction. Although the foreign policy establishment of the EU appears to have been developed in the form of the Political and Security Committee and the Western European Union, in practice a coherent political direction may be difficult to achieve.

- There may still be occasions when the interests of NATO clash with those of the European Union. One might speculate that middle east tensions, which spill over into Turkey or Cyprus and southern Europe may evoke a very varying response from the USA and the EU. 
A key aspect of defence (and foreign) policy concerns intelligence. It may be difficult for European powers to share intelligence, an area where there is a notorious amount of secrecy and national self-interest.

\section{EU defence and foreign policy abbreviations and definitions}

- NATO: North Atlantic Treaty Organisation. Responsible for the collective security of Europe and the Western World. Comprises most European states plus the USA and Canada.

- WEU: Western European Union. The section of NATO comprising only European states.

- CFSP: Common Foreign and Security Policy. The European Union's commitment to adopt agreed common foreign policies.

- CESDP: Common European Security and Defence Policy. The agreement to co-operate on internal defence matters.

- PSC: Political and Security Committee. A permanent body whose role is to provide political direction for any military actions.

- EMC: European Military Committee. A committee of officials who have the task of coordinating military policy.

- EMS: European Military Staff. Officers of European armed forces who co-ordinate military arrangements.

\section{EUROPEAN RIGHTS AND CITIZENSHIP}

Most European states have adopted the European Convention of Human Rights. However this does not mean that the principle of human rights has been fully established throughout Europe. Some states, including the UK, do not treat it as binding and it is not fully comprehensive.

Civil rights campaigners have, as two of their goals, the establishment of a European Bill of Rights and a universal concept of European citizenship. At Maastricht this idea was built into the objectives of the EU, although little progress has been made since. What does this mean in principle?

1 It implies that there will be a codified set of rights to which all citizens of the European Union will be entitled. These rights would include those contained in the European Convention plus the economic and social rights which are contained in the EU Social Chapter.

2 These rights would be binding on all EU members, so that all laws and executive actions would have to conform.

3 A European Court - presumably the existing Court of Justice - would have powers to enforce these rights.

4 All citizens of member countries would gain all the rights contained in the Bill of Rights. 
5 The rules for citizenship, i.e. who is entitled to call themselves a citizen of the European Union, would be common to all member states.

6 There would have to be common rules of naturalization and other means of acquiring citizenship which would apply throughout Europe.

On the face of it, there might be little problem in codifying such a set of principles. Most countries already conform to most of the same rules and there would be little argument over those terms already contained in the European Convention and the Social Chapter. Nevertheless there are potential problems. Some of the main ones are:

- Those countries and politicians who are worried about the growing power of the EU and the loss of national identities would perhaps object to the concept of European citizenship. They would place national identity above a European identity, and would be concerned if Europe were placed above the nation in this matter.

- There are likely to be disagreements about the rules by which individuals could become citizens of Europe. What, for example, would be the future status of refugees and asylum seekers? Who would decide whether such people should be entitled to apply for citizenship? It has to be remembered that, if citizenship were granted, the person concerned would have the right to live and work in any part of the Union.

- There might not be total agreement about what rights should be granted to all citizens. Most would be agreed, but perhaps not all. This may be a particular problem for new members who do not have the same tradition of rights as the rest of western Europe.

- Some countries, notably the UK with its doctrine of parliamentary sovereignty, might be unwilling to accept that a European Court could overrule elements of its legislation or could overturn the actions of its government.

So the development of European rights and citizenship is likely to remain a contentious issue. It calls into question fundamental questions of sovereignty and implies that national governments would lose control over who would be admitted to their territory. It also brings closer the concept that individuals may be expected to owe a higher allegiance to Europe than to their nation of birth or adoption.

\section{THE EFFECTS OF THE SINGLE CURRENCY}

The development of the single currency has, of course, been of great importance to the European project. However, it is no longer a live political issue. The single currency is here to stay for the time being and its successful introduction in early 2002 confirms that there is little point in discussing its advantages and 
disadvantages. For the UK and the other two states who did not enter the system in 2002 it is still a contentious matter, but for the twelve existing members of the Euro-zone the discussions are over.

But the effects of the single currency will still be far-reaching. It is worth, at this stage, reminding ourselves what problems and difficulties are likely to arise.

- The role of the European Central Bank, which will control interest rates and, indirectly, the fiscal policies of member states, is likely to become controversial, especially as it is unelected and unaccountable.

- If there is an economic crisis or serious recession, there will be those who suggest that it is the single currency which is the culprit.

- Similarly, if any individual states run into economic difficulty and discover that the European Bank cannot help them, and that their own governments find their hands tied by centralised policies, their own public may become disenchanted with the single currency system.

- If the external value of the euro declines, resulting in European inflation, support for the euro may ebb away.

- As economic harmonisation increases while the currency has its effect, there may be a reaction against the uniformity and loss of national sovereignty which has arisen from the single currency.

Yet, despite all this, the problems of returning to fifteen or more individual currencies would seem to be now impractical, so discussion of such issues remains largely academic and speculative.

\section{SAMPLE QUESTIONS}

1 What is meant by the term 'democratic deficit'? What proposals have been made to correct it?

2 What are the main problems associated with the Common Agricultural Policy?

3 Why is enlargement such a problem for the European Union?

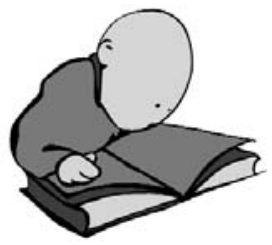

4 What are the main problems associated with the development of common foreign and defence policies for the European Union?

5 Is it possible to develop the concept of European citizenship? 